\title{
PRODUKTIVITAS DAN MUTU JAGUNG HIBRIDA PENGEMBANGAN DARI JAGUNG LOKAL PADA KONDISI INPUT RENDAH SEBAGAI SUMBER BAHAN PAKAN TERNAK AYAM
}

\author{
Mubarakkan, M. Taufik, Bieng Brata \\ Program Studi Pascasarjana Pengelolaan Sumberdaya Alam dan Lingkungan, Fakultas \\ Pertanian Universitas Bengkulu
}

\begin{abstract}
ABSTRAK
Kebutuhan produk berbahan baku jagung untuk pakan ternak, bahan pangan dan industri lainnya di Indonesia setiap tahunnya terus meningkat. Produktivitas jagung nasional yang rendah hingga saat ini belum mampu memenuhi kebutuhan domestik tersebut, sehingga harus dilakukan impor jagung. Upaya peningkatan produktivitas melalui perakitan jagung hibrida baru yang superior dari jagung lokal menghasilkan jagung hibrida yang adaptif pada berbagai kondisi lahan dan mempunyai produktivitas tinggi pada kondisi input rendah. Tujuan penelitian adalah untuk mengetahui penampilan agronomis, produktivitas dan nilai gizi jagung hibrida pengembangan dari jagung lokal pada kondisi input rendah sebagai sumber bahan pakan ternak ayam.Penelitian dilakukan di lahan percobaan SPP Kelobak di Desa Kelobak Kabupaten Kepahiang pada bulan Desember 2011 hingga Mei 2012 menggunakan Rancangan Acak Kelompok Lengkap tiga ulangan. Penelitian menggunakan 12 jagung hibrida baru dan 2 hibrida pembanding yaitu Bisi 12 dan Bisi 816. Kondisi input rendah dilakukan dengan pemberian pupuk anorganik yang terdiri dari pupuk Urea $150 \mathrm{~kg} / \mathrm{ha}, \mathrm{SP} 36$ $50 \mathrm{~kg} / \mathrm{ha}$, KCL $25 \mathrm{~kg} / \mathrm{ha}$, dan insektisida carbofuran $10 \mathrm{~kg} / \mathrm{ha}$. Hasil penelitian menunjukkan bahwa semua hibrida menunjukkan keragaan tanaman yang hampir sama. Hasil biji pipilan kering tertinggi (10,60 ton/ha) ditunjukkan oleh hibrida 14, yang berbeda nyata dengan hibrida pembanding Bisi 12 dan Bisi 816 dengan hasil masing-masing 9,58 dan 8,29 ton/ha. Kandungan protein tertinggi ditunjukkan oleh hibrida 4 dan 8 dengan kadar 14,12\%, yang sangat sesuai untuk bahan pakan ternak ayam, sedangkan hibrida 1 dan 13 dengan kandungan karbohidrat 805 dan $790 \mathrm{mg}$ glukosa/gBK lebih sesuai dikembangkan sebagai sumber bahan pangan.
\end{abstract}

Kata kunci : Jagung hibrida, input rendah, pakan ternak ayam

\section{PENDAHULUAN}

Kebutuhan produk berbahan baku jagung untuk pakan ternak, bahan pangan dan industri di Indonesia setiap tahunnya terus meningkat. Di Indonesia, jagung merupakan komoditi tanaman pangan kedua terpenting sebagai sumber karbohidrat setelah beras. Hingga akhir tahun 2010 impor jagung mencapai 2,5 juta ton dari kebutuhan 5,5 juta ton atau meningkat $65 \%$ dari tahun 2009. Namun hingga saat ini produksi jagung nasional belum mampu untuk memenuhi kebutuhan domestik yang mencapai 11 juta ton/tahun. Kebutuhan jagung terbesar digunakan untuk industri pakan $57 \%$, bahan pangan $34 \%$ dan $9 \%$ untuk kebutuhan lainnya.

Penggunaan jagung sebagai bahan baku utama industri pakan ternak mengalami peningkatan seiring dengan tumbuhnya sektor industri pakan ternak di Indonesia. Hingga akhir tahun 2011 besarnya impor jagung diperkirakan mencapai 2,5 juta ton khusus untuk pakan ternak (Sudirman, 2011). Tingginya kebutuhan jagung untuk bahan pakan ternak disebabkan karena penggunaan jagung dalam penyusunan 
komposisi pakan bisa mencapai $52 \%$ sebagai sumber protein dan energi bagi ternak.

Provinsi Bengkulu yang merupakan salah satu daerah penghasil jagung hanya mampu memproduksi jagung sebanyak 115.254 ton pada tahun 2008, tahun 2009 sebanyak 105.710 ton berkurang 8,28\% dari tahun 2008 (BPS Bengkulu, 2010). Upaya peningkatan produksi jagung di Provinsi Bengkulu telah dilakukan melalui peningkatan produktivitas tanaman per hektar dan perluasan areal tanam. Namun demikian, meski sudah menggunakan benih varietas jagung hibrida produktivitas rata-rata saat ini baru mencapai 3,3 ton/ha (BPS Provinsi Bengkulu, 2010), demikian juga produktivitas jagung secara nasional hanya mencapai 4,2 ton/ha (BPS, 2010), jauh dari potensinya yang bisa mencapai lebih dari 10 ton/ha.

Penggunaan jagung hibrida yang berproduksi tinggi meski secara ekonomis lebih menguntungkan bagi petani, namun dari sisi konservasi cukup mengancam keberadaan jagung varietas lokal yang merupakan sumber keragaman plasma nutfah lokal. Oleh karena itu pemanfaatan jagung hibrida pengembangan dari jagung lokal merupakan solusi yang tepat untuk mengatasi kekurangan pasokan bahan pakan ternak yang terjadi saat ini. Hasil perakitan jagung hibrida yang berdaya hasil dan bernilai gizi tinggi pada kondisi input rendah sangat diperlukan untuk meningkatkan produktivitas yang ada saat ini. Pemberian input rendah dapat mengurangi biaya produksi dan ramah lingkungan.

Penelitian ini bertujuan untuk mengetahui penampilan agronomis, produktivitas dan nilai gizi jagung hibrida pengembangan dari jagung lokal pada kondisi input rendah.

\section{METODA PENELITIAN}

\section{Lokasi dan waktu}

Penelitian dilakukan di lahan percobaan SPP Kelobak, Desa Kelobak Kabupaten Kepahiang bulan Desember 2011 hingga Mei 2012.

\section{Pengambilan data}

\section{Rancangan percobaan}

Penelitian menggunakan Rancangan Acak Kelompok Lengkap dengan 3 (tiga) ulangan, sehingga diperoleh 42 (empat puluh dua) satuan petak percobaan. Penelitian diawali dengan pembersihan dan pengolahan tanah menggunakan traktor, selanjutnya dibuat blok dan petakpetak percobaan. Ukuran setiap petak percobaan $4,5 \times 2,5 \mathrm{~m}$, jarak antar petak 50 $\mathrm{cm}$ dan jarak antar blok atau ulangan 100 $\mathrm{cm}$. Penanaman dilakukan dengan tugal, satu biji per lubang tanam, jarak tanam yang digunakan $75 \times 25 \mathrm{~cm}$, sehingga setiap petak terdiri dari 60 tanaman. Penyulaman dilakukan 1 minggu setelah tanam (mst) dengan menanam kembali benih yang tidak tumbuh pada setiap petak percobaan.

Bahan penelitian menggunakan 14 jagung hibrida terdiri dari 12 jagung hibrida baru dan 2 hibrida pembanding, yakni Bisi 12 dan Bisi 816. Pupuk anorganik yang digunakan terdiri dari pupuk Urea, SP36 dan KCL dengan dosis rendah $(150 \mathrm{~kg} / \mathrm{ha}$ Urea, $50 \mathrm{~kg} / \mathrm{ha} \mathrm{SP} 36$ dan $25 \mathrm{~kg} / \mathrm{ha} \mathrm{KCL}$ ). Insektisida yang digunakan hanya carbofuran $10 \mathrm{~kg} / \mathrm{ha}$.

\section{Pemeliharaan dan pemanenan tanaman}

Pemupukan dilakukan pada saat tanam dengan dosis urea, SP-36 dan $\mathrm{KCl}$ masing-masing 50, 50 dan $25 \mathrm{~kg} / \mathrm{ha}$. Campuran pupuk urea, SP-36 dan $\mathrm{KCl}$ dimasukkan dalam larikan sedalam $5 \mathrm{~cm}$ dengan jarak $7 \mathrm{~cm}$ dari lubang tanam, selanjutnya larikan ditutup dengan tanah. Pada pemupukan susulan pertama dan kedua hanya diberikan pupuk urea dengan dosis masing-masing $50 \mathrm{~kg} / \mathrm{ha}$ diberikan pada saat tanaman berumur 4 dan 6 minggu setelah tanam (mst). Pupuk urea 
dimasukkan dalam larikan sedalam $5 \mathrm{~cm}$ dengan jarak $15 \mathrm{~cm}$ dari tanaman jagung, selanjutnya larikan ditutup dengan tanah.

Penyiraman dilakukan jika tidak turun hujan dengan menyiram tanaman hari sekali, dengan cara mengalirkan air melalui selang plastik hingga tanah menjadi lembab. Jika terjadi hujan lebat, saluran drainase dibuat untuk menghindari tanaman jagung dari genangan air. Pengendalian gulma dilakukan secara manual dengan cara mencabuti gulma yang tumbuh pada petak-petak penelitian. Pembumbunan hanya dilakukan sekali pada waktu tanaman jagung berumur 3 mst. Pemanenan dilakukan pada stadium masak fisiologis dengan ciri-ciri tongkol jagung sudah berwarna kuning, jika tongkol dikupas biji akan tampak keras, bernas dan mengkilap serta bila ditekan dengan kuku tangan tidak menunjukkan bekas tekanan.

\section{Variabel yang diamati}

Pengamatan dan pengukuran dilakukan pada variabel utama dan variabel penunjang, yaitu: tinggi tanaman $(\mathrm{cm})$, diameter batang $(\mathrm{cm})$, umur berbunga (hst), umur tongkol keluar rambut (hst), tinggi tongkol $(\mathrm{cm})$, umur panen (hst), diameter tongkol tanpa kelobot $(\mathrm{cm})$, panjang tongkol $(\mathrm{cm})$, jumlah baris biji per tongkol, jumlah biji per baris, bobot 1000 biji $(\mathrm{g})$, bobot tongkol basah $(\mathrm{g})$, hasil pipilan kering $(\mathrm{g})$, rendemen $(\%)$ dan nilai nutrisi. Analisis kimia dilakukan di laboratorium dengan menggunakan metode analisis proksimat terhadap 100 gram sampel masing-masing hibrida untuk mengetahui kandungan nutrisi yang terdiri dari protein, lemak, karbohidrat, serat kasar dan gross energi.

Variabel penunjang yang diamati, yaitu stay green, bentuk tongkol, susunan baris biji, warna biji, tekstur (tipe biji), tingkat penutupan kelobot (husk cover) dan keragaan tanaman.

\section{Analisis data}

Data yang diperoleh dianalisis secara statistik menggunakan anova dengan uji $\mathrm{F}$ pada taraf $5 \%$, dan bila terdapat perbedaan yang nyata dilakukan uji lanjut Duncan's Multiple Range Test (DMRT) pada taraf 5 $\%$.

\section{HASIL DAN PEMBAHASAN}

\section{Kondisi lingkungan}

Tanah di lokasi penelitian termasuk jenis tanah Andosol. Hasil analisis laboratorium menunjukan tekstur tanah terdiri dari pasir $73,30 \%$, debu $15,36 \%$ dan liat $11,34 \%$, dengan $\mathrm{pH} \mathrm{H}_{2} \mathrm{O} 5,9$ (agak masam), pH KCL 5,3 dengan kadar C-organik tanah 2,55\% (sedang). Kadar $\mathrm{N}$-total 0,34\% (sedang), $\mathrm{P}_{2} \mathrm{O}_{5}$ Bray Kurtz I sangat tinggi $(22,20 \mathrm{ppm}), \quad \mathrm{K}$-tersedia sangat rendah (1,46 me/100 gram), Ca-dd dan Mg-dd masing-masing 21,06 me/100 gram dan 0,11 me/100 gram, H-dd dan KTK masing-masing 0,05 me/100 gram dan 24,54 me/100 gram (tinggi).

Curah hujan rata-rata bulanan di lokasi penelitian adalah 185 - $337 \mathrm{~mm}$ dengan jumlah hari hujan $22-27$ hari. Kondisi ini sangat ideal untuk mendukung pertumbuhan tanaman jagung yang mempunyai kebutuhan air cukup tinggi selama masa pertumbuhan. Kebutuhan air ideal bagi tanaman jagung berkisar antara 85-200 mm yang akan meningkat pada fase pembungaan dan pengisian biji. Kekurangan air pada saat 3 minggu setelah keluar rambut tongkol akan menurunkan hasil hingga $30 \%$, sementara kekurangan air selama pembungaan akan mengurangi jumlah biji yang terbentuk (Anonim, 2010; Purwono, 2010). Suhu udara rata-rata $23^{\circ}$ $\mathrm{C}$ dan kelembaban nisbi rata-rata $83-91 \%$.

\section{Produksi dan mutu jagung}


Semua genotip yang diuji menunjukkan tingkat pertumbuhan dan hasil yang sangat baik yaitu 9,10 ton/hektar, angka ini jauh diatas rata-rata produktivitas jagung hibrida saat ini yang hanya mencapai 3,3 ton/ha (BPS Provinsi Bengkulu, 2010), dan produktivitas nasional 4,2 ton/ha (BPS, 2010). Hasil analisis varians (Anava) untuk menguji pengaruh genotipe hibrida pada variabel pertumbuhan dan hasil 14 jagung hibrida yang diamati selama penelitian disajikan pada Tabel 1 .

Tabel 1. Analisis varians variabel pengamatan 14 jagung hibrida

\begin{tabular}{clcc} 
No. & \multicolumn{1}{c}{$\begin{array}{c}\text { Variabel } \\
\text { Pengamatan }\end{array}$} & Kuadrat Tengah & $\begin{array}{c}\text { Tingkat } \\
\text { Signifikansi }\end{array}$ \\
\hline 1 & Tinggi tanaman & $0,029^{*}$ & 0,016 \\
2 & Diameter batang & $0,062^{* *}$ & 0,000 \\
3 & Umur berbunga & $2,432^{*}$ & 0,003 \\
4 & Umur tongkol keluar rambut & $3,150^{*}$ & 0,002 \\
5 & Tinggi tongkol & $0,024^{*}$ & 0,002 \\
6 & Umur panen & $4,390^{*}$ & 0,002 \\
7 & Diameter tongkol tanpa kelobot & $0,163^{* *}$ & 0,000 \\
8 & Panjang tongkol & $3,844^{n s}$ & 0,006 \\
9 & Jumlah baris biji per tongkol & $1,520^{n s}$ & 0,236 \\
10 & Jumlah biji per baris & $4,025^{n s}$ & 0,179 \\
11 & Bobot 1000 biji & $0,000^{*}$ & 0,044 \\
12 & Bobot tongkol basah & $747,458^{n s}$ & 0,203 \\
14 & Hasil pipilan kering & $4,201^{* *}$ & 0,000 \\
15 & Rendemen & $2,705^{* *}$ & 0,000 \\
\hline
\end{tabular}

Keterangan : $\begin{aligned}<0,01 & =\text { berbeda sangat nyata }(* *) \\ 0,01-0,05 & =\text { berbeda nyata }(*) \\ >0,05 & =\text { tidak berbeda nyata }(\mathrm{ns})\end{aligned}$

Tabel 2. Hasil pipilan kering dan kandungan nutrisi jagung hibrida.

\begin{tabular}{clcccc}
\hline & & \multicolumn{4}{c}{ Variabel Pengamatan } \\
\cline { 3 - 6 } No. & Genotipe & $\begin{array}{c}\text { Hasil pipilan } \\
\text { kering (ton/ha)* }\end{array}$ & $\begin{array}{c}\text { Protein } \\
(\%)^{* *}\end{array}$ & $\begin{array}{c}\text { Lemak } \\
(\%)^{* *}\end{array}$ & $\begin{array}{c}\text { Karbohidrat } \\
(\text { mg glukosa/gBK)** }\end{array}$ \\
\hline 1 & Hibrida 1 & $9,8800^{\mathrm{d}-\mathrm{e}}$ & 11,25 & 4,55 & 805 \\
2 & Hibrida 2 & $8,8000^{\mathrm{b}-\mathrm{c}}$ & 11,74 & 3,59 & 635 \\
3 & Hibrida 3 & $9,6267^{\mathrm{d}}$ & 9,59 & 3,57 & 635 \\
4 & Hibrida 4 & $8,4633^{\mathrm{b}}$ & 14,12 & 3,93 & 655 \\
5 & Hibrida 5 & $7,9833^{\mathrm{a}-\mathrm{b}}$ & 11,14 & 5,77 & 588 \\
6 & Bisi 12 & $9,5833^{\mathrm{c}-\mathrm{d}}$ & 12,82 & 5,84 & 450 \\
7 & Bisi 816 & $8,2967^{\mathrm{b}}$ & 11,90 & 3,99 & 590 \\
8 & Hibrida 8 & $9,5133^{\mathrm{c}-\mathrm{d}}$ & 14,12 & 4,46 & 545 \\
9 & Hibrida 9 & $10,1833^{\mathrm{d}-\mathrm{e}}$ & 11,09 & 3,76 & 596 \\
10 & Hibrida 10 & $8,7900^{\mathrm{b}-\mathrm{c}}$ & 12,74 & 4,00 & 608 \\
11 & Hibrida 11 & $8,2300^{\mathrm{b}}$ & 11,46 & 4,61 & 631 \\
12 & Hibrida 12 & $10,0900^{\mathrm{d}-\mathrm{e}}$ & 10,61 & 4,44 & 654 \\
13 & Hibrida 13 & $7,4300^{\mathrm{a}}$ & 9,96 & 4,27 & 790 \\
14 & Hibrida 14 & $10,6000^{\mathrm{e}}$ & 9,95 & 4,80 & 680 \\
\hline & Rata-rata & 9,10 & 11,61 & 4,40 & 633
\end{tabular}

Keterangan : *) Hasil uji lanjut DMRT taraf $5 \%$, angka-angka yang diikuti huruf yang sama pada kolom yang sama tidak menunjukan perbedaan yang nyata.

**) Hasil Analisis pada Lab. Terpadu Departemen Agronomi dan Hortikultura. Fakultas Pertanian IPB. (2012) 
Tabel 2 menunjukkan bahwa 14 genotipe jagung hibrida yang diuji berpengaruh nyata terhadap variabel tinggi tanaman, diameter batang, umur berbunga, umur tongkol keluar rambut, tinggi tongkol, umur panen dan diameter
Hasil uji kadar energi menunjukkan Bisi 12 dengan persentase bahan kering 95,99\% mengandung kadar gross energi tertinggi $4.144 \mathrm{kal} / \mathrm{g}$ bahan kering . Hibrida 2, 4, 8, 11, 12 dan 14 mengandung gross energi antara $4.022-4.083 \mathrm{kal} / \mathrm{g}$ Tabel 3. Kadar bahan kering, serat kasar dan gross energi 14 hibrida

\begin{tabular}{clccc}
\hline \multirow{2}{*}{ No.} & Genotipe & $\begin{array}{c}\text { Bahan Kering/ } \\
\text { BK }(\%)\end{array}$ & $\begin{array}{c}\text { Serat Kasar/ } \\
\text { SK }(\%)\end{array}$ & $\begin{array}{c}\text { Gross Energi/ } \\
\text { GE(kal/gram) }\end{array}$ \\
\hline 1 & Hibrida 1 & 95,34 & 2,79 & 3697 \\
2 & Hibrida 2 & 95,52 & 2,72 & 4022 \\
3 & Hibrida 3 & 92,95 & 2,39 & 3774 \\
4 & Hibrida 4 & 94,87 & 2,20 & 4053 \\
5 & Hibrida 5 & 94,97 & 2,69 & 3816 \\
6 & Hibrida 12 & 95,99 & 2,21 & 4144 \\
7 & Hibrida 816 & 94,31 & 2,96 & 3783 \\
8 & Hibrida 8 & 93,04 & 2,92 & 4079 \\
9 & Hibrida 9 & 89,54 & 2,15 & 3787 \\
10 & Hibrida 10 & 89,75 & 2,80 & 3947 \\
11 & Hibrida 11 & 89,39 & 2,87 & 4083 \\
12 & Hibrida 12 & 89,91 & 2,84 & 4033 \\
13 & Hibrida 13 & 88,87 & 2,09 & 3948 \\
14 & Hibrida 14 & 92,18 & 2,10 & 4033 \\
\hline & Rata-rata & 92,62 & 2,55 & 3942,79 \\
\hline
\end{tabular}

Sumber : Hasil Analisis pada Laboratorium Ilmu dan Teknologi Pakan. Departemen Ilmu Nutrisi dan Teknologi Pakan. IPB. (2012)

tongkol tanpa kelobot, kecuali untuk variabel panjang tongkol menunjukkan pengaruh tidak nyata. Genotipe berpengaruh nyata pada sebagian variabelvariabel hasil dan komponen hasil, yaitu bobot seribu biji, hasil pipilan kering dan rendemen dan tidak berpengaruh nyata terhadap jumlah baris biji per tongkol, jumlah biji per baris dan bobot tongkol basah.

Perakitan jagung hibrida varietas unggul baru bertujuan untuk menciptakan jagung hibrida yang mampu berproduksi tinggi pada kondisi input rendah dan mempunyai kadar nutrisi yang tinggi. Hasil analisis kadar bahan kering, serat kasar, protein, lemak dan karbohidrat 14 jagung hibrida yang diuji laboratorium menunjukkan kandungan rata-rata bahan kering 92,62 \%, serat kasar 2,55\%, protein 11,61\%, lemak 4,40 \% dan karbohidrat 663,00 mg glokusa/g bahan kering. bahan kering lebih tinggi dari kadar energi rata-rata 3.939 kalori/gram bahan kering. Jagung dengan kadar energi terendah yakni hibrida 1 dengan kadar bahan kering 95,34 persen mengandung energi 3.697 $\mathrm{kal} / \mathrm{g}$ bahan kering, lebih rendah dari ratarata tanaman pembanding $3.963 \mathrm{kal} / \mathrm{g}$ bahan kering. Nilai rata-rata kadar energi sebesar $3.939 \mathrm{kal} / \mathrm{g}$ berat kering yang dihasilkan kedua belas jagung hibrida yang diuji sangat sesuai untuk digunakan sebagai pakan sumber energi ternak, khususnya ayam karena masih memiliki kadar energi yang lebih baik jika dibandingkan dengan rata-rata hasil analisis kadar energi jagung yang pernah dianalisis sebelumnya yakni antara 3.310 $3.350 \mathrm{kkal} / \mathrm{kg}$ (Widodo, 2006; Agus, 2007; Anonim, 2010; Nawawi, 2011).

Hasil uji lanjut DMRT $5 \%$ terhadap variabel-variabel agronomis 14 hibrida yang diuji (Tabel 4.) menunjukan hibrida $2,3,12,9,8,1,10$ dan 11 memiliki 
pertumbuhan yang lebih tinggi dibandingkan dengan Bisi 12 dan Bisi 816 dengan tinggi masing-masing 2,16 $\mathrm{m}$ dan 2,15 $\mathrm{m}$, namun pertumbuhan kedua hibrida pembanding masih lebih tinggi dibandingkan dengan hibrida 14, 13, 4 dan nyata dengan Bisi 12, Bisi 816, hibrida 10,3,5,11,9,2,14, dan 1 yang memiliki jumlah biji per baris 37,86-40,00. (Tabel 5)

Perbedaan jumlah baris biji per tongkol dan jumlah biji per baris meskipun

Tabel 3. Hasil uji lanjut DMRT $5 \%$ terhadap umur panen, bobot tongkol basah, rendemen dan hasil pipilan kering

\begin{tabular}{|c|c|c|c|c|c|}
\hline \multirow[b]{2}{*}{ No. } & \multirow[b]{2}{*}{ Genotipe } & \multicolumn{4}{|c|}{ Variabel } \\
\hline & & $\begin{array}{l}\text { Umur panen } \\
\text { (hst) }\end{array}$ & $\begin{array}{l}\text { Bobot tongkol } \\
\text { basah (ton/ha) }\end{array}$ & $\begin{array}{l}\text { Hasil pipilan } \\
\text { kering (ton/ha) }\end{array}$ & $\begin{array}{c}\text { Rendemen } \\
(\%)\end{array}$ \\
\hline 1 & Hibrida 1 & $109,00^{d}$ & $12,2267^{f-g}$ & $9,8800^{\mathrm{d}-\mathrm{e}}$ & $81,00^{a-c}$ \\
\hline 2 & Hibrida 2 & $106,67^{a-c}$ & $11,1567^{\mathrm{d}-\mathrm{e}}$ & $8,8000^{b-c}$ & $78,67^{\mathrm{a}}$ \\
\hline 3 & Hibrida 3 & $108,67^{c-d}$ & $12,0167^{\mathrm{e}-\mathrm{g}}$ & $9,6267^{\mathrm{d}}$ & $79,63^{a-b}$ \\
\hline 4 & Hibrida 4 & $106,00^{a-b}$ & $10,3067^{b-d}$ & $8,4633^{b}$ & $82,00^{b-c}$ \\
\hline 5 & Hibrida 5 & $108,67^{\mathrm{c}-\mathrm{d}}$ & $9,6367^{\mathrm{a}-\mathrm{b}}$ & $7,9833^{a-b}$ & $83,00^{c}$ \\
\hline 6 & Bisi 12 & $109,33^{\mathrm{d}}$ & $11,8700^{\mathrm{e}-\mathrm{f}}$ & $9,5833^{c-d}$ & $81,00^{\mathrm{a}-\mathrm{c}}$ \\
\hline 7 & Bisi 816 & $108,33^{\mathrm{c}-\mathrm{d}}$ & $10,1933^{b-c}$ & $8,2967^{b}$ & $81,67^{b-c}$ \\
\hline 8 & Hibrida 8 & $107,67^{b-d}$ & $11,7233^{\text {e-f }}$ & $9,5133^{\mathrm{c}-\mathrm{d}}$ & $81,33^{a-c}$ \\
\hline 9 & Hibrida 9 & $106,67^{a-c}$ & $12,3333^{f-g}$ & $10,1833^{\mathrm{d}-\mathrm{e}}$ & $82,33^{\mathrm{b}-\mathrm{c}}$ \\
\hline 10 & Hibrida 10 & $108,33^{c-d}$ & $10,5800^{c-d}$ & $8,7900^{\mathrm{b}-\mathrm{c}}$ & $83,33^{c}$ \\
\hline 11 & Hibrida 11 & $108,33^{c-d}$ & $10,0067^{\mathrm{a}-\mathrm{c}}$ & $8,2300^{b}$ & $82,33^{b-c}$ \\
\hline 12 & Hibrida 12 & $107,33^{a-d}$ & $12,3100^{f-g}$ & $10,0900^{\text {d-e }}$ & $82,00^{b-c}$ \\
\hline 13 & Hibrida 13 & $108,67^{c-d}$ & $9,1633^{\mathrm{a}}$ & $7,4300^{\mathrm{a}}$ & $81,00^{a-c}$ \\
\hline 14 & Hibrida 14 & $105,33^{a}$ & $12,9433^{\mathrm{g}}$ & $10,6000^{\mathrm{e}}$ & $81,67^{\mathrm{b}-\mathrm{c}}$ \\
\hline Rata-rata & Klp. & 107,79 & 11,1762 & 9,10 & 81,50 \\
\hline KK (\%) & & 1,01 & 4,52 & 4,83 & - \\
\hline Rata-rata & Hibrida & 107,61 & 11,20 & 9,13 & 81,52 \\
\hline Rata-rata & Bisi & 108,83 & 11,05 & 8,94 & 81,34 \\
\hline
\end{tabular}

Keterangan : Angka-angka yang diikuti huruf yang sama pada kolom yang sama tidak menunjukan perbedaan yang nyata.

5. Komponen hasil tanaman

menunjukan hibrida 1 memiliki diameter tongkol tanpa klobot terbesar $5,47 \mathrm{~cm}$ berbeda nyata dengan Bisi 12 dan 816, hibrida 5, 13, dan 4, yang memiliki diameter tongkol tanpa klobot 4,79-4,94 $\mathrm{cm}$.

Diameter tongkol yang besar akan menyediakan ruang yang cukup bagi terbentuknya biji. Hibrida 9 dan 2 yang memiliki jumlah baris biji 16,13 tidak berbeda nyata dengan Bisi 12, Bisi 816, hibrida 4, 14, 3, 10, 1, 8, 12, dan 11 dengan rata-rata jumlah baris biji 14,60 - 15,73. Namun berbeda nyata dengan hibrida 5 dan 13 dengan jumlah baris biji rata-rata 13, 86. Jumlah biji per baris terbanyak pada hibrida $12(40,93)$ tidak berbeda berpengaruh terhadap besar kecilnya biji yang dihasilkan namun tidak menunjukan perbedaan yang nyata terhadap bobot biji. Hasil uji DMRT taraf 5\% tidak menunjukan adanya perbedaan yang nyata pada semua hibrida. Bobot 1000 biji pada seluruh tanaman yang diuji berkisar antara $276,33-319,67$ gr, bobot terendah ditunjukan oleh Bisi 816 dan tertinggi hibrida 3 dengan rata-rata 12 hibrida 300,78 gr. Bobot ini masih lebih baik bila dibandingkan dengan bobot rata-rata dua hibrida pembanding yaitu 287,67 gr.

Bobot 1000 biji yang tidak berbeda nyata pada semua tanaman yang diuji ini menunjukan bahwa seluruh tanaman mampu untuk tumbuh dan berproduksi baik pada kondisi input rendah dengan 
memanfaatkan kondisi lingkungan yang terbatas secara optimal. Dengan rata-rata rendemen 81,50 persen secara keseluruhan dua belas hibrida yang diuji coba dalam penelitian ini memiliki tingkat rendemen yang tinggi dan potensial untuk dikembangkan.

Hasil penghitungan tingkat stay green (Tabel 5.) menunjukan hibrida 9, 8 dan 1
$19,61 \mathrm{~cm}$ dan susunan baris biji dalam tongkol yang tersusun lurus teratur. Biji yang dihasilkan berwarna kuning dengan bagian luar biji yang terdiri dari pati keras dan licin sehingga masuk dalam kelompok tanaman jagung dengan tipe biji semi mutiara. Kelobot umumnya menutup rapat dengan baik dan dapat diikat menjadi satu pada ujung tongkol (skor 1). Hasil

Tabel 4. Hasil uji lanjut DMRT taraf uji $5 \%$ terhadap penampilan agronomis jagung hibrida

\begin{tabular}{|c|c|c|c|c|c|c|c|}
\hline \multirow[b]{2}{*}{ No. } & \multirow[b]{2}{*}{ Genotipe } & \multicolumn{6}{|c|}{ Variabel } \\
\hline & & $\begin{array}{l}\text { Tinggi } \\
\text { Tanaman } \\
\text { (m) }\end{array}$ & $\begin{array}{l}\text { Diameter } \\
\text { Batang } \\
(\mathrm{cm})\end{array}$ & $\begin{array}{c}\text { Umur } \\
\text { Berbunga } \\
\text { (hst) }\end{array}$ & $\begin{array}{l}\text { Umur } \\
\text { Tngkol } \\
\text { Klr. Rambut } \\
\text { (hst) }\end{array}$ & $\begin{array}{l}\text { Tinggi } \\
\text { Tongkol } \\
(\mathrm{m})\end{array}$ & $\begin{array}{c}\text { Panjang } \\
\text { Tongkol } \\
(\mathrm{cm})\end{array}$ \\
\hline 1 & Hibrida 1 & $2,2693^{a-d}$ & $2,2733^{\mathrm{d}-\mathrm{e}}$ & $62,3333^{a-c}$ & $65,6667^{b-d}$ & $0,8633^{a-d}$ & $20,5333^{c-d}$ \\
\hline 2 & Hibrida 2 & $2,4500^{\mathrm{d}}$ & $2,3667^{\mathrm{c}-\mathrm{e}}$ & $63,3333^{c-d}$ & $65,3333^{b-d}$ & $1,0600^{\mathrm{e}}$ & $19,0667^{\mathrm{a}-\mathrm{d}}$ \\
\hline 3 & Hibrida 3 & $2,3333^{\mathrm{c}-\mathrm{d}}$ & $2,2933^{\mathrm{c}-\mathrm{e}}$ & $62,3333^{a-c}$ & $64,0000^{a-b}$ & $0,9600^{\mathrm{c}-\mathrm{e}}$ & $19,2667^{\mathrm{a}-\mathrm{d}}$ \\
\hline 4 & Hibrida 4 & $2,1200^{\mathrm{a}-\mathrm{b}}$ & $2,0567^{\mathrm{a}-\mathrm{b}}$ & $63,6667^{\mathrm{c}-\mathrm{d}}$ & $65,0000^{a-d}$ & $0,7900^{a-b}$ & $18,0677^{\mathrm{a}}$ \\
\hline 5 & Hibrida 5 & $2,1067^{\mathrm{a}}$ & $2,0800^{\mathrm{a}-\mathrm{b}}$ & $64,3333^{\mathrm{d}}$ & $66,0000^{\mathrm{c}-\mathrm{d}}$ & $0,8267^{\mathrm{a}-\mathrm{c}}$ & $18,4667^{\mathrm{a}-\mathrm{c}}$ \\
\hline 6 & Bisi 12 & $2,1633^{a-c}$ & $1,9800^{\mathrm{a}}$ & $64,3333^{d}$ & $66,6667^{\mathrm{d}}$ & $0,8100^{\mathrm{a}-\mathrm{c}}$ & $18,5667^{\mathrm{a}-\mathrm{c}}$ \\
\hline 7 & Bisi 816 & $2,1567^{\mathrm{a}-\mathrm{c}}$ & $2,2467^{\mathrm{b}-\mathrm{e}}$ & $63,0000^{b-d}$ & $65,6667^{b-d}$ & $0,9100^{b-e}$ & $18,6000^{a-c}$ \\
\hline 8 & Hibrida 8 & $2,2733^{\mathrm{a}-\mathrm{d}}$ & $2,2000^{\mathrm{b}-\mathrm{c}}$ & $62,3333^{a-c}$ & $64,6667^{a-c}$ & $0,9367^{\text {b-e }}$ & $\underset{d}{20,4333^{b-}}$ \\
\hline 9 & Hibrida 9 & $2,2800^{\mathrm{a}-\mathrm{d}}$ & $2,4000^{\mathrm{d}-\mathrm{e}}$ & $62,3333^{a-c}$ & $64,0000^{a-b}$ & $0,9667^{c-e}$ & $20,6000^{c-d}$ \\
\hline 10 & Hibrida 10 & $2,2677^{\mathrm{a}-\mathrm{d}}$ & $2,4200^{\mathrm{e}}$ & $62,3333^{a-c}$ & $64,0000^{a-b}$ & $0,9500^{c-e}$ & $\underset{d}{20,4667^{b-}}$ \\
\hline 11 & Hibrida 11 & $2,2600^{a-d}$ & $2,2067^{b-d}$ & $63,0000^{b-d}$ & $65,0000^{a-d}$ & $0,9467^{\text {c-e }}$ & $18,3333^{a-b}$ \\
\hline 12 & Hibrida 12 & $2,3133^{b-d}$ & $2,2933^{\mathrm{c}-\mathrm{e}}$ & $61,3333^{a}$ & $63,3333^{a}$ & $1,0667^{\mathrm{d}-\mathrm{e}}$ & $21,0000^{\mathrm{d}}$ \\
\hline 13 & Hibrida 13 & $2,1400^{\mathrm{a}-\mathrm{c}}$ & $1,9867^{\mathrm{a}}$ & $62,3333^{a-c}$ & $64,0000^{a-b}$ & $0,8767^{\mathrm{a}-\mathrm{d}}$ & $18,3333^{a-b}$ \\
\hline 14 & Hibrida 14 & $2,1533^{\mathrm{a}-\mathrm{c}}$ & $2,2067^{b-d}$ & $61,6667^{\mathrm{a}-\mathrm{b}}$ & $63,3333^{a}$ & $0,7467^{\mathrm{a}}$ & $21,1000^{\mathrm{d}}$ \\
\hline & $\begin{array}{l}\text { ata-rata } \\
\text { lompok }\end{array}$ & 2,2348 & 2,2150 & 62,7619 & 64,7619 & 0,9078 & 19,49 \\
\hline Rata & ata Hibrida & 2,25 & 2,23 & 62,61 & 64,53 & 0,92 & 19,64 \\
\hline & -rata Bisi & 2,16 & 2,11 & 63,67 & 66,17 & 0,86 & 18,58 \\
\hline & $\mathrm{K}(\%)$ & 4,69 & 67,19 & 1,32 & 1,43 & 8,53 & 5,64 \\
\hline
\end{tabular}

Keterangan: Angka-angka yang diikuti huruf yang sama pada kolom yang sama tidak menunjukan perbedaan yang nyata pada uji DMRT taraf uji $5 \%$

memiliki tingkat stay green yang lebih tinggi dibandingkan dengan hibrida lainnya, dengan rata-rata berturut-turut adalah $87,85 \%, 87,16 \%$ dan $87,05 \%$. Hibrida 13 dengan tingkat persentase stay green terendah $82,52 \%$ masih sangat baik untuk digunakan sebagai sumber hijauan makanan ternak. Pengamatan variabel penunjang dilakukan secara manual di lapangan mulai dari dua minggu setelah anthesis hingga tanaman sudah matang fisiologis dan siap untuk dipanen serta setelah tanaman dipanen.

Semua hibrida yang diamati rata-rata memiliki bentuk tongkol yang panjang dan lurus dengan rata-rata panjang tongkol pengamatan variabel pertumbuhan dan hasil secara keseluruhan dari mulai tanaman tumbuh hingga panen menunjukan bahwa tingkat keragaan tanaman secara keseluruhan sangat baik (skor 1).

Berdasarkan hasil analisis terhadap semua variabel yang diamati, dapat disimpulkan bahwa semua tanaman dapat tumbuh baik dan mampu beradaptasi terhadap kondisi lingkungan penelitian yang ada. Perlakuan pemberian pupuk dosis rendah ternyata tidak menghambat proses pertumbuhan dan menurunkan hasil tanaman secara signifikan. 


\section{KESIMPULAN}

Berdasarkan hasil evaluasi terhadap variabel utama dan variabel penunjang dapat disimpulkan bahwa semua jagung hibrida yang ditanam pada kondisi input rendah memiliki tingkat adaptasi dan keragaan tanaman yang hampir sama. Dengan tingkat produktivitas rata-rata 9,10 ton/ha, seluruh tanaman sangat potensial
Anonim. 2010. Pedoman Bertanam Jagung. Nuansa Aulia. Bandung. . 2010. Makanan Pokok, Makan Ternak dan Energi. http://majalahenergi.com/energibar audan terbarukan/bioenergi/

Badan Pusat Statistik. 2010. Statistik Indonesia. Jakarta. BPS.

Badan Pusat Statistik. 2010. Produksi Padi

Tabel 5. Hasil uji lanjut DMRT taraf uji $5 \%$ pada komponen hasil tanaman dan Hasil pengamatan stay green

\begin{tabular}{|c|c|c|c|c|c|c|}
\hline \multirow[b]{2}{*}{ No. } & \multirow[b]{2}{*}{ Genotipe } & \multicolumn{4}{|c|}{ Variabel } & \multirow[b]{2}{*}{$\begin{array}{c}\text { Stay } \\
\text { Green } \\
(\%)\end{array}$} \\
\hline & & $\begin{array}{l}\text { D. Tongkol } \\
\text { T. Kelobot } \\
(\mathrm{cm})^{*}\end{array}$ & $\begin{array}{l}\text { Jlh. Baris Biji } \\
\text { per Tongkol* }\end{array}$ & $\begin{array}{c}\text { Jlh. Biji } \\
\text { per Baris* }\end{array}$ & $\begin{array}{c}\text { Bobot } \\
1000 \text { biji } \\
(\mathrm{gr})^{*}\end{array}$ & \\
\hline 1 & Hibrida 1 & $5,4667^{b}$ & $15,3333^{a-b}$ & $40,0000^{a-b}$ & $315,00^{a}$ & 87,05 \\
\hline 2 & Hibrida 2 & $5,3533^{b}$ & $16,1333^{b}$ & $39,8667^{a-b}$ & $298,33^{a}$ & 85,99 \\
\hline 3 & Hibrida 3 & $5,3600^{b}$ & $15,0667^{\mathrm{a}-\mathrm{b}}$ & $38,6000^{a-b}$ & $319,67^{\mathrm{a}}$ & 88,44 \\
\hline 4 & Hibrida 4 & $4,8833^{\mathrm{a}}$ & $14,6000^{a-b}$ & $37,1667^{\mathrm{a}}$ & $283,00^{\mathrm{a}}$ & 83,88 \\
\hline 5 & Hibrida 5 & $4,7933^{a}$ & $13,8667^{\mathrm{a}}$ & $38,7333^{a-b}$ & $279,67^{\mathrm{a}}$ & 84,24 \\
\hline 6 & Bisi 12 & $4,9433^{\mathrm{a}}$ & $14,6000^{a-b}$ & $38,6667^{\mathrm{a}-\mathrm{b}}$ & $299,00^{a}$ & 86,51 \\
\hline 7 & Bisi 816 & $4,9267^{\mathrm{a}}$ & $14,9333^{a-b}$ & $39,0000^{\mathrm{a}-\mathrm{b}}$ & $276,33^{\mathrm{a}}$ & 86,16 \\
\hline 8 & Hibrida 8 & $5,2933^{b}$ & $15,4000^{a-b}$ & $40,4000^{b}$ & $317,67^{\mathrm{a}}$ & 87,16 \\
\hline 9 & Hibrida 9 & $5,3533^{b}$ & $16,1333^{b}$ & $39,5333^{a-b}$ & $317,33^{a}$ & 87,85 \\
\hline 10 & Hibrida 10 & $5,2133^{b}$ & $15,0667^{\mathrm{a}-\mathrm{b}}$ & $37,8667^{\mathrm{a}-\mathrm{b}}$ & $283,33^{a}$ & 85,98 \\
\hline 11 & Hibrida 11 & $5,1933^{b}$ & $15,7333^{a-b}$ & $39,0000^{a-b}$ & $282,67^{\mathrm{a}}$ & 85,26 \\
\hline 12 & Hibrida 12 & $5,3267^{b}$ & $15,6000^{a-b}$ & $40,9333^{b}$ & $304,33^{a}$ & 88,03 \\
\hline 13 & Hibrida 13 & $4,8467^{\mathrm{a}}$ & $13,8667^{\mathrm{a}}$ & $37,0000^{\mathrm{a}}$ & $296,00^{a}$ & 82,52 \\
\hline 14 & Hibrida 14 & $5,3533^{b}$ & $14,8000^{a-b}$ & $39,8667^{\mathrm{a}-\mathrm{b}}$ & $312,33^{\mathrm{a}}$ & 88,09 \\
\hline \multicolumn{2}{|c|}{ Rata-rata Klpk. } & 5,1647 & 15,0809 & 39,0452 & 298,90 & 88,88 \\
\hline \multicolumn{2}{|c|}{ Rata-rata Hibrida } & 5,20 & 15,13 & 39,08 & 300,78 & 86,20 \\
\hline \multicolumn{2}{|c|}{ Rata-rata Bisi } & 4,94 & 14,77 & 38,83 & 287,67 & 86,33 \\
\hline \multicolumn{2}{|c|}{ KK (\%) } & 2,74 & 6,97 & 68,17 & 7,59 & - \\
\hline
\end{tabular}

Keterangan : *) Angka-angka yang diikuti huruf yang sama pada kolom yang sama tidak menunjukan perbedaan yang nyata pada uji DMRT taraf uji $5 \%$

untuk dikembangkan sebagai sumber pangan dan pakan ternak. Hibrida 4 dan 8 dengan kandungan protein 14,12\% termasuk dalam jagung protein mutu tinggi (Quality Protein Maize) yang sangat sesuai sebagai bahan pakan ternak ayam, sedangkan hibrida 1 dan 13 dengan kandungan karbohidrat 805 dan 790 mg glukosa/gBK lebih sesuai untuk dikembangkan sebagai sumber bahan pangan.

\section{DAFTAR PUSTAKA}

Agus, A. 2007. Membuat Pakan Ternak Secara Mandiri. Yogyakarta. Citra Aji Permana. dan Palawija Provinsi Bengkulu 2002 - 2009. Bengkulu. Badan Pusat Statistik Provinsi Bengkulu.

Nawawi, N.T., dan Nurrohmah, S. 2011. Pakan Ayam Kampung. Penebar Swadaya. Jakarta.

Purwono dan R. Hartono. 2010. Bertanam Jagung Unggul. Penebar Swadaya. Jakarta.

Sudirman. 2011. Impor Jagung Terus Naik.

http://www.businessnews.co.id/ featured/ ketua-gpmt-imporjagung-terus-naik.php. Desember 2011).

Taufik, M., Suprapto dan Heru Widiyono. 2010. Uji Daya hasil Pendahuluan Jagung Hibrida di Lahan Ultisol 
ISSN:

dengan Input Rendah. Akta Agrosia Vol. 13 No. 1 : 70-76.

Widodo, W. 2006. Nutrisi dan Pakan Unggas

Kontekstual. http://wahyuwidodo.staff.umm.ac.id /files/2010/01/nutrisi_dan_pakan_u nggas_kontekstual. 